\title{
Rooting of apical cuttings of Angelonia integerrima Sprengel: concentrations of indole-3-butyric acid and substrates ${ }^{(1)}$
}

\author{
MARA CÍNTIA WINHELMANN(2)*, GISLAINE TAÍS GRZEÇA ${ }^{(2)}$, AQUÉLIS ARMILIATO EMER(2), MARÍLIA TEDESCO(2), \\ PRISCILA PARIS(2), JOANA PAOLAZZI(2), CLAUDIMAR SIDNEI FIOR(2), GILMAR SCHAFER(2)
}

\begin{abstract}
The objective of this study was to evaluate the effect of the concentration of indole-3-butyric acid (IBA) and substrates in the rooting of apical cuttings of Angelonia integerrima. Powder IBA was used at the concentrations 0, 500, 1,000, 2,000 and 4,000 mg $\mathrm{kg}^{-1}$, and two substrates containing carbonized rice husks (CRH) and commercial substrate based on Sphagnum peat were used. The number of rooted cuttings, shoot length, root system length, number of new leaves, root system volume, callus formation at the cutting base, and shoot and root dry matter were evaluated. The experimental design was completely randomized with a factorial design (5 IBA concentrations $\mathrm{x} 2$ substrates). There were no interactions between the concentrations of IBA and the substrates. There was a difference only for the factor substrate. The cuttings presented an average rooting of $79 \%$, with callus formation in $59.4 \%$ of them. The $\mathrm{CRH}$ substrate presented the highest shoot length and the highest number of new leaves. The commercial substrate resulted in a high average root volume, a large root length and a great increase in root dry matter. In the rooting by cutting of $A$. integerrima is not necessary to use IBA and the commercial substratum based on peat or CRH can be used.
\end{abstract}

Keywords: vegetative propagation, floriculture, native ornamental specie.

\section{RESUMO}

Enraizamento de estaca apicais de Angelonia integerrina Sprengel: concentrações de ácido indol-3-butírico e substratos O objetivo do trabalho foi avaliar o efeito da concentração de ácido indol-3-butírico (AIB) e substratos no enraizamento de estacas

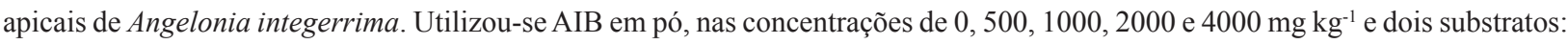
casca de arroz carbonizada (CAC) e substrato comercial a base de turfa de Sphagnum. Avaliou-se: número de estacas enraizadas, comprimento da parte aérea e do sistema radicular, número de folhas novas, volume do sistema radicular, formação de calo na base da estaca, massa seca da parte aérea e do sistema radicular. O delineamento experimental foi inteiramente casualizado, em esquema fatorial (5 concentrações de AIB x 2 substratos). Não houve interação entre as concentrações de AIB e substratos, somente houve diferença para o fator substrato. As estacas apresentaram enraizamento médio de 79\%, com formação de calo em 59,4\%. O substrato CAC promoveu maior comprimento da parte aérea e maior número de folhas novas. O substrato comercial proporcionou maior volume médio de raiz, maior comprimento de raiz e maior incremento de massa seca radicular. No enraizamento por estaquia de A. integerrima não é necessário usar AIB e pode-se utilizar o substrato comercial à base de turfa ou a CAC.

Palavras-chave: propagação vegetativa, floricultura, espécie ornamental nativa.

\section{INTRODUCTION}

The genus Angelonia originates in the Neotropical region, which covers the area from central Mexico to the southern tip of South America (BOFF et al., 2014). The emergence of different species is not yet fully understood (PLASCHIL and OLBRICHT, 2008; GOSCH et al., 2014), with report of approximately 50 species (TROPICOS, 2018), and differences related to the shape and color of the flower, ranging between blue, violet, white and pink (GOSCH et al., 2014). The genus can be found in all Brazilian biomes and in the most diverse types of vegetation, including Caatinga, Altitude Field, Clean Field,
Rupestrian Field, Cerrado, Dryland Forest, Ombrophilous Forest and Restinga, being registered 18 species in Brazil (REFLORA, 2018).

Angelonia integerrima Sprengel is known by the popular name of 'violeta-do-campo' (field violet) or Angelonia, being an herbaceous and perennial species, up to $40 \mathrm{~cm}$ high, occurring in rock outcrops and stony fields. The stem color is burgundy, with oblong and opposing leaves. The flowers are arranged in terminal branches, with white to light lilac coloration, with some purple tint. Flowering occurs from October to March. This species has ornamental potential, as it can be cultivated in flower beds, flower boxes and pots, as well as used as a complement

DOI: http://dx.doi.org/10.14295/oh.v24i2.1149

(1) Received in 03/02/2018 and accepted in 25/05/2018

(2) Universidade Federal do Rio Grande do Sul, Departamento de Horticultura e Silvicultura, Porto Alegre-RS, Brasil. *Corresponding author: marawinhelmann@yahoo.com.br

Licensed by CC BY 4.0 
in floral arrangements (BURKART, 1979; STUMPF et al., 2009). There are no reports of $A$. integerrima propagation to date, but vegetative propagation may be an alternative.

Asexual propagation, also called vegetative propagation, occurs through the multiplication of plants from any plant structure capable of forming roots (KÄMPF, 2005). It consists in the multiplication of plants by a process that does not involve gametes, but rather from the potentiality of the cell to regenerate a plant (BARBOSA and LOPES, 2007).

Regarding the asexual production of seedlings, the advantages are the possibility of obtaining individuals with greater fidelity to the phenotypic characteristics of the mother plant, greater seedling production rate, giving a higher precocity to the plants produced, and eventual fixation of desired somatic variations (KÄMPF, 2005; NEVES et al., 2006; GROLLI, 2008). However, for using mother plants for the supply of propagating material, it is necessary to maintain them in an appropriate place with adequate management. Some cutting-propagated species have disadvantages, such as lower multiplication rate and higher risk of transmission of vascular, bacterial and viral diseases (KÄMPF, 2005; GROLLI, 2008).

In many species, it is difficult to induce the formation of adventitious roots, which decreases the rooting percentage, since cuttings at different physiological maturity points show a different behavior in relation to rooting. In this context, the use of auxins may help this process, being a very common practice (NEVES et al., 2006). The rooting of cuttings is a genetically controlled phenomenon and requires the presence of auxin, which induces the formation of the root primordia. There is often an unbalance in the natural levels of this hormone, so it is necessary to use regulators exogenous to the plant, for instance, synthetic auxins such as indole butyric acid (IBA) and naphthaleneacetic acid (NAA) (PAIVA et al., 2005).

Younger cuttings have higher concentrations of natural auxin, so a lower number of exogenous regulators can be provided to induce the rooting process. Pruning can be used as a form of rejuvenation to obtain new cuttings, as the dedifferentiation process occurs with the formation of buds (NEVES et al., 2006).

In the production of seedlings by cutting, the choice of a suitable substrate is of fundamental importance. It must provide enough water to avoid cutting dewatering, and facilitate the supply of oxygen, with adequate pore space, to begin the process of root formation (YAMAMOTO et al., 2013).

It is also noteworthy the growth habit of many species of Angelonia, such as Angelonia cornigera Hook.; besides being an herbaceous species, its shoots occur just above the ground, and the stem emission above ground level occurs at flowering, that is, this stem gives rise to the inflorescence, then senesces and dies, however new shoots sprout from the base of the plant, which will again flourish (MACHADO et al., 2002). This same behavior was verified for $A$. integerrima, although not described in the scientific literature. In this sense, to evaluate propagation techniques of these species is fundamental for the conservation thereof, and is also a way of divulging the natural patrimony of a region (BARROSO et al., 2009), in addition to being a source of information to technicians and producers regarding seedling production.

In recent years, there has been a constant search for new species with ornamental potential (BECKMANNCAVALCANTE et al., 2014). To date, there is no information on the commercial exploitation of A. integerrima, as well as no information on its propagation was found in the literature. Given that it is a promising species to be used in floriculture, it is important to know how to propagate it, since its seeds did not germinate through conventional methods in multicellular trays with substrate, in tests performed prior to this work. Therefore, the objective of the present work was to evaluate the effect of indole-3butyric acid concentration and substrates in the rooting of apical cuttings of $A$. integerrima.

\section{MATERIAL AND METHODS}

Mother plants from in vitro seeding of propagating material collected in situ in the municipality of Barão do Triunfo (RS) were cultivated in 5L pots, containing Carolina Soil ${ }^{\circledR}$ commercial substrate. The plants were kept in a drip irrigation system and were fertilized biweekly with $2 \mathrm{~g} \mathrm{~L}^{-1}$ of Kristalon yellow ${ }^{\circledR}$ (NPK: 6-12-36), applied by fertigation at a volume of $50 \mathrm{~mL}$ per plant.

At 5 months of cultivation, a drastic pruning was performed in the plants to stimulate sprouting. After 30 days, the apical cuttings were collected, being standardized for $6 \pm 0.5 \mathrm{~cm}$ in length and two buds (each one protected by a leaf), which were cut remaining at half the initial size. During and after the preparation of the cuttings, they were kept submerged in water to avoid dehydration and oxidation of the plant material. The basal end of each cutting was cut into a beveled shape and then placed in contact with powdered IBA, being diluted with talc (Pó Pelotense ${ }^{\circledR}$ ) to the concentrations of 0 (control), 500, 1,000, 2,000 and 4,000 mg kg-1. Subsequently, they were immediately transferred to multicellular polypropylene trays containing 50 cells with $100 \mathrm{~mL}$ volume each, which were filled by two different substrates: a) carbonized rice husk (CRH); and b) commercial substrate containing Sphagnum peat, expanded vermiculite, $\mathrm{CRH}$, dolomitic limestone, agricultural gypsum and NPK fertilizer (Carolina Soil ${ }^{\circledR}$ ). The physical and chemical analysis of the substrates was performed by according to IN No. 17, May 21, 2007 (BRASIL, 2007).

The cuttings were inserted into the substrate at approximately $1 \mathrm{~cm}$ depth and then taken to a nebulization chamber, which had intermittent nebulization, controlled by timer, in nebulization cycles of 15 seconds every 5 minutes, with relative humidity higher than $90 \%$.

The period of the experiment was from January 26 to April 11, 2016, with the cuttings remaining in the nebulization chamber all the time. The recorded average temperatures of the period were $25.1^{\circ} \mathrm{C}$ (medium), $29.6{ }^{\circ} \mathrm{C}$ (maximum) and $20.7^{\circ} \mathrm{C}$ (minimum).

The following evaluations were performed at 76 days after the installation of the experiment: number of rooted cuttings, length of shoots and roots, number of new leaves, root volume, callus formation at the base of the cutting, dry mass of shoots and roots. The length of shoots and 
roots were obtained with the aid of a millimeter ruler. Root volume was obtained through the volume of water displaced, from a known volume. Roots and shoots were oven dried at $65 \pm 5{ }^{\circ} \mathrm{C}$ until constant weight and then weighed on a precision scale.

The experimental design was completely randomized, in a $5 \times 2$ factorial scheme (5 IBA concentrations $\times 2$ substrates), with five replicates of ten cuttings per plot. The data were submitted to analysis of variance (ANOVA) and subsequently the means were compared by the Tukey test at $5 \%$ probability of error, using the SigmaPlot 11.0 software. The callus percentage data did not meet ANOVA assumptions and were transformed to $\mathrm{x}^{2}$.

\section{RESULTS AND DISCUSSION}

The analysis of variance showed that, for all analyzed variables, there was no interaction between IBA concentrations and the substrates tested (Table 1). There was also no statistical difference for the different variables analyzed with respect to IBA concentrations, with difference only for the substrate factor (Table 1).

Table 1. Analysis of variance of the cutting of Angelonia integerrima Sprengel, submitted to different concentrations of IBA and substrates.

\begin{tabular}{|c|c|c|c|c|}
\hline Variables Analyzed & Substrate $\boldsymbol{P}$ value & IBA concentration $\boldsymbol{P}$ value & Interaction $\boldsymbol{P}$ value & CV (\%) \\
\hline Rooting (\%) & 0.53 & 0.22 & 0.46 & 8.60 \\
\hline Callus (\%) & $<0.01$ & 0.33 & 0.45 & 31.4 \\
\hline Length of shoots (cm) & $<0.01$ & 0.88 & 0.88 & 23.4 \\
\hline Length of roots (cm) & 0.01 & 0.73 & 0.32 & 6.40 \\
\hline Number of new leaves & $<0.01$ & 0.85 & 0.52 & 39.4 \\
\hline Root volume (mL) & 0.01 & 0.57 & 0.85 & 22.9 \\
\hline Dry mass of shoots (g) & 0.81 & 0.72 & 0.90 & 11.5 \\
\hline Dry mass of roots (g) & $<0.01$ & 0.56 & 0.96 & 31.8 \\
\hline
\end{tabular}

$\mathrm{CV}=$ coefficient of variation

The cuttings had a mean rooting of $79 \%$, with no of the growth regulators used (Table 2), showing that statistical difference for the substrates and the concentrations Angelonia shows rooting at high rates of apical cuttings.

Table 2. Influence of concentrations of indole-3-butyric acid (IBA) and substrates on the rooting percentage $\mathrm{R}(\%)$, on the percentage of callus formation Callus (\%), shoot length (SL), root length (RL), number of new leaves (number of NL), root volume (RV), dry mass of shoot (DMS) and roots (DMR) of Angelonia integerrima Sprengel cutting.

\begin{tabular}{|c|c|c|c|c|c|c|c|c|}
\hline $\begin{array}{c}\text { Concentration IBA } \\
\left(\mathrm{mg} \mathrm{kg}^{-1}\right)\end{array}$ & R (\%) & Callus (\%) & SL (cm) & RL (cm) & Number of NL & $\mathbf{R V}(\mathbf{m L})$ & DMS (g) & DMR (g) \\
\hline 0 & $71 \mathrm{a}$ & $70 a$ & $9.16 \mathrm{a}$ & $9.89 \mathrm{a}$ & $8.49 a$ & $0.33 \mathrm{a}$ & $0.13 \mathrm{a}$ & $0.04 \mathrm{a}$ \\
\hline 500 & $83 a$ & $58 \mathrm{a}$ & $9.79 a$ & $9.90 \mathrm{a}$ & $8.81 \mathrm{a}$ & $0.30 \mathrm{a}$ & $0.12 \mathrm{a}$ & $0.04 \mathrm{a}$ \\
\hline 1000 & $77 \mathrm{a}$ & $49 a$ & $9.02 \mathrm{a}$ & $9.73 a$ & $8.30 \mathrm{a}$ & $0.26 \mathrm{a}$ & $0.10 \mathrm{a}$ & $0.03 a$ \\
\hline 2000 & $86 a$ & $55 \mathrm{a}$ & $10.12 \mathrm{a}$ & $9.70 \mathrm{a}$ & $9.40 \mathrm{a}$ & $0.33 \mathrm{a}$ & $0.14 \mathrm{a}$ & $0.04 \mathrm{a}$ \\
\hline 4000 & $80 \mathrm{a}$ & $65 \mathrm{a}$ & $9.51 \mathrm{a}$ & $10.35 \mathrm{a}$ & $9.01 \mathrm{a}$ & $0.28 \mathrm{a}$ & $0.12 \mathrm{a}$ & $0.04 \mathrm{a}$ \\
\hline Average & 79.4 & 59.4 & 9.52 & 9.91 & 8.80 & 0.30 & $0.12 \mathrm{a}$ & 0.04 \\
\hline \multicolumn{9}{|l|}{ Substrate } \\
\hline $\mathrm{CRH}^{1}$ & $78.1 \mathrm{a}$ & $34.7 \mathrm{~b}$ & $11.56 \mathrm{a}$ & $9.49 \mathrm{~b}$ & $12.02 \mathrm{a}$ & $0.24 \mathrm{~b}$ & $0.12 \mathrm{a}$ & $0.03 \mathrm{~b}$ \\
\hline Commercial $^{2}$ & $80.7 \mathrm{a}$ & $84.1 \mathrm{a}$ & $7.48 \mathrm{~b}$ & $10.34 \mathrm{a}$ & $5.59 \mathrm{~b}$ & $0.36 \mathrm{a}$ & $0.12 \mathrm{a}$ & $0.05 \mathrm{a}$ \\
\hline Average & 79.4 & - & - & - & - & - & 0.12 & - \\
\hline
\end{tabular}

${ }^{1} \mathrm{CRH}=$ carbonizer rice husks; ${ }^{2}$ Commercial substrate based on Sphagnum peat; averages followed by distinct letters in the column differ from each other by the Tukey test at $5 \%$ probability of error. 
This suggests that this species has sufficient endogenous levels of auxin, since the formation of adventitious roots, through the cutting process, occurs from differentiated cells that divide themselves and later develop the apical meristem of the root (TAIZ and ZEIGER, 2013). Leaves or stem cuttings begin to form adventitious roots near the cut region, due to the IAA accumulation occurring in the site, resulting from the interruption in the polar transport of this auxin (KERBAUY, 2013).

In the cultivation of Podranea ricasoliana (Tanfani) Sprague, the authors also did not verify difference in the rooting of cuttings when using IBA, reaching an average rooting of $45.2 \%$ (TEDESCO et al., 2016). In the cultivation of Sinningia lineata (Hjelmq.) Chautems, 100\% rooting of cuttings was verified (BARROSO et al., 2009), showing that this variable is species dependent.

In cuttings of Aloysia gratissima (Gillies and Hook.) Tronc., a higher rooting percentage was observed in herbaceous cuttings, as they showed higher retention of leaves when compared to semi-woody cuttings, with leaves being an endogenous source of auxin (SANTOS et al., 2009). As in this work, the same amount of buds and leaves per cutting was kept, and so this may explain the fact that there was no difference in the rooting percentage, even with the supply of exogenous auxin, probably because the species has this phytohormone in sufficient levels, since it presented rooting without the need of IBA.

For the substrate factor, in the vegetative propagation of Oncimum selloi (Benth), a native medicinal species, the authors also did not verify difference in the rooting percentage when using $\mathrm{CRH}$, washed sand and a commercial substrate (COSTA et al., 2007). In cuttings of Baccharis trimera (Less.), different substrates were also tested, among them $\mathrm{CRH}$, not showing differences in relation to the rooting percentage (BONA et al., 2005). These results are in accordance with the present work, indicating that the species is not demanding with respect to the characteristics of the substrates.

Another important variable is the root volume. In this work, it did not present differences for the different concentrations of IBA, but it is important to emphasize that the regulators can also influence the quality of the root system (FACHINELLO et al., 2005), which will have a direct relation with seedling development, as well as with their survival at transplant (LIMA and OHASHI, 2016), consequently presenting faster and more vigorous growth (REIS et al., 2000). Similar results were obtained in the rooting of Campomanesia aurea O. Berg cuttings, where IBA also had no influence on root system quality (EMER et al., 2016). Moreover, in cuttings of Mikania micrantha Kunth (FERRIANI et al., 2007) and Jasminum mesnyi Hanceos (ALTHAUS et al., 2007), the authors found that the use of synthetic auxin increased the length of the roots formed, influencing their quality.

Callus formation occurred in $59.4 \%$ of the cuttings, and the peat-based substrate promoted 2.4 times greater callus formation when compared to $\mathrm{CRH}$ (Table 2). In some species, callus formation at the base of the cuttings may serve as a physical barrier for root development, while in others it may represent the beginning of adventitious root formation (FACHINELLO et al., 2005). In the present work, callus may have been the precursor of root formation, since rooted cuttings were obtained with the presence of callus.

The CRH substrate increased about 1.5 times in shoot length when compared to the peat-based substrate and was also higher (by more than twice) the mean number of roots formed (Table 2). Notwithstanding, the variable dry mass of shoots presented no statistical difference, with a general average of $0.12 \mathrm{~g}$ (Table 2). Even though the CRH substrate favored a larger shoot length, this did not influence dry mass accumulation, since it had a low concentration of salts, which may affect the initial development of the cuttings.

$\mathrm{CRH}$ can be used purely in the rooting of cuttings or in mixture with other materials, since it presents low density and low water retention capacity, in addition to providing good aeration, due to the high percentage of macropores (KÄMPF, 2005). It promotes rapid and efficient drainage (KÄMPF, 2005), given that organs such as roots present intense respiration (KERBAUY, 2013), so the need to provide a substrate that shows adequate physical characteristics, which considers the aeration space (AS).

The physical analysis of CRH (Table 3) showed that it had total porosity (TP) of $71.6 \%$ and aeration space (AS) of $47.7 \%$, while the commercial substrate had 82.8 and $33.3 \%$, respectively.

Table 3. Chemical and physical analysis of the substrates used in rooting of Angelonia integerrima Sprengel.

\begin{tabular}{|c|c|c|}
\hline Variables & $\mathrm{CRH}^{1}$ & Commercial $^{2}$ \\
\hline pH & 7.49 & 6.15 \\
\hline $\mathrm{EC}\left(\mathrm{mS} \mathrm{cm} \mathrm{cm}^{-1}\right)$ & 0.13 & 0.35 \\
\hline WD (\%) & 71.56 & 82.78 \\
\hline AS (\%) & 47.72 & 33.26 \\
\hline WA (\%) & 14.57 & 19.52 \\
\hline WR (\%) & 9.28 & 30.00 \\
\hline
\end{tabular}

${ }^{1} \mathrm{CRH}=$ carbonized rice husks; ${ }^{2} \mathrm{Commercial}$ substrate; $\mathrm{pH}=$ potential of hydrogen; $\mathrm{EC}=$ electric conductivity; $\mathrm{WD}=$ wet density; $\mathrm{AS}=$ aeration space; $\mathrm{WA}=$ water available; $\mathrm{WR}=$ water remaining. 
The TP comprises micro and macropores, the former retaining the water and the latter being responsible for its infiltration and subsequent drainage, with consequent aeration of the medium (DRZAL et al., 1999), so the ideal substrate presenting a value of $85 \%$ TP (DE BOODT and VERDONCK, 1972). Regarding chemical characteristics, the CRH presented a $\mathrm{pH}$ value close to neutrality (7.49) and EC of $0.13 \mathrm{mS} \mathrm{cm}^{-1}$.

In Rhododendron simsii Planch. rooting of the cuttings, when using different substrates, it was verified that CRH and vermiculite provided a greater number of leaves, whereas coconut fiber had the lowest values for this variable (LONE et al., 2010). The same can be observed for this work, since the CRH presented a larger number of leaves when compared with the commercial substrate.

The peat-based substrate provided and in increase in root volume of 1.5 times the one verified for substrate CRH (Table 2). As for root length, the peat-based substrate had increased by $10 \%$ the value when compared to $\mathrm{CRH}$. However, for the variable dry mass of roots, the commercial substrate presented results $60 \%$ higher than $\mathrm{CRH}$ (Table 2).

The peat can be used pure or in mixtures to aid in the improvement of physical or chemical characteristics of the substrates (KÄMPF, 2005). The substrate may influence the quality of the roots formed (FACHINELLO et al., 2005). In the present work, it was observed that the peatbased commercial substrate provided higher mean volume, length and dry mass of roots. This substrate has basic NPK fertilization in its composition, with EC of $0.35 \mathrm{mS} \mathrm{cm} \mathrm{cm}^{-1}$ and $\mathrm{pH}$ of 6.15 . Such a fact may have contributed to a better quality of the root system, as it is directly related with the survival of plants at transplant and subsequent development, due to the greater ability to absorb water and nutrients (SANTORO et al., 2010).

Cloning is a method that can be used by growers to produce seedlings; they can keep selected mother plants in the greenhouse, which will provide the material needed for propagation. This work is a precursor, since it was verified that it is possible to perform the cloning of $A$. integerrima of the cutting method, even though the apical cuttings will give rise to inflorescences. It is not necessary to use IBA, since the species showed a satisfactory rooting.

\section{CONCLUSIONS}

The process of rooting of Angelonia integerrima cuttings is feasible for the conditions of this work, not being necessary to use IBA. Peat-based commercial substrate or carbonized rice husk can be used.

\section{ACKNOWLEDGMENTS}

The authors are thankful to Capes, CNPq and FAPERGS for the financial support of this research.

\section{AUTHORS CONTRIBUTION}

M.C.W.: Responsible for the implementation, evaluation and writing of the article; G.T.G.: assisted in the implantation and the evaluation of the experiment; A.A.E.: assisted in the implantation and the evaluation of the experiment; M.T.: assisted in the implantation and the evaluation of the experiment; P.P.: assisted in the implantation and the evaluation of the experiment; J.P.: assisted in the implantation and the evaluation of the experiment; C.S.F.: Co-adviser, assisted in the correction of the article; G.S.: Adviser assisted in the preparation of the study and correction of the article.

\section{REFERENCES}

ALTHAUS, M.M.; LEAL, L.; SILVEIRA, F.; ZUFFELLATO-RIBAS, K.C.; RIBAS, L.L.F. Influência do ácido naftaleno acético e dois tipos de substrato no enraizamento de estacas de jasmim-amarelo. Revista Ciência Agronômica, v.38, n.3, p.322-326, 2007.

BARBOSA, J.C.; LOPES, L.C. Propagação de plantas ornamentais. Viçosa: Editora UFV, 2007. 183p.

BARROSO, C.M.; BARROS, I.B.I.D.; FRANKE, L.B.; GLOVACK, B.; FOCHESATO, M.L. Propagação vegetativa de Sinningia lineata (Hjelmq.) Chautems, rainha-do-abismo. Ornamental Horticulture, v.14, n.2, p.159-168, 2009. DOI: https://doi.org/10.14295/rbho. v14i2.286

BECKMANN-CAVALCANTE, M.Z.; AMARAL, G.C.; AVELINO, R.C.; BRITO, L.P. da S.; CAVALCANTE, Í.H.L. Propagação de Alternanthera dentata pelo processo de estaquia em função de tipo de estaca, AIB e época do ano. Comunicata Scientiae, v.5, n.2, p170-177, 2014.

BOFF, S.; DEMARCO, D.; MARCHI, P.; ALVES-DOSSANTOS, I. Perfume production in flowers of Angelonia salicariifolia attracts males of Euglossa annectans which do not promote pollination. Apidologie, v.46, n.1, p.84-91, 2014. DOI: $10.1007 / \mathrm{s} 13592-014-0305-2$

BONA, C.M. de; BIASI, L.A.; ZANETTE, F.; NAKASHIMA, T. Estaquia de três espécies de Baccharis. Ciência Rural, v.35, n.1, p.223-226, 2005. DOI: http:// dx.doi.org/10.1590/S0103-84782005000100037 
BRASIL. Ministério da Agricultura, Pecuária e abastecimento(MAPA). Secretaria deDefesaAgropecuária (SDA). Instrução Normativa SDA No 17 de 21 de maio de 2007. Métodos Analíticos Oficiais para Análise de Substratos e Condicionadores de Solos. Diário Oficial da União, Brasília, DF, 2007. 7p. Available in: <http://extranet.agricultura.gov. $\mathrm{br} /$ sislegis-consulta/servlet/VisualizarAnexo?id=14783>. Acessed on: February 03, 2018.

BURKART, A. Parte V: Dicotiledoneas Metaclamideas. In: FLORA Ilustrada de Entre Rios (Argentina). Tomo VI, parte $5^{\text {a }}$. Buenos Aires: Instituto Nacional de Technologia Agropecuaria, 1979. p.481-484.

COSTA, L.C. do B.; PINTO, J.E.B.P.; BERTOLUCCI, S.K.V. Comprimento da estaca e tipo de substrato na propagação vegetativa de atroveran. Ciência Rural, v.37, n.4, p.1157-1160, 2007. DOI: http://dx.doi.org/10.1590/ S0103-84782007000400040

DE BOODT, M.; VERDONCK, O. The physical properties of the substrates in horticulture. Acta Horticulturae, n.26, p.37-44, 1972. DOI: 10.17660/ActaHortic.1972.26.5

DRZAL, M.A.; FONTENO, W.C., CASSEL, D.K. Pore fraction analysis: a nex tool for substrate testing. Acta Horticulturae, v.1, p.43-54, 1999. DOI: https://doi. org/10.17660/ActaHortic.1999.481.1

EMER, A.A.; SCHAFER, G.; AVRELLA, E.D.; DELAZERI, M.; VEIT, P.A.; FIOR, C.S. Influence of indolebutyric acid in the rooting of Campomanesia aurea semihardwood cuttings. Ornamental Horticulture, v.22, n.1, p.94-100, 2016. DOI: https://doi.org/10.14295/ oh.v22i1.855

FACHINELLO, J.C.; HOFFMANN, A.; NACHTIGAL, J.C. Propagação de plantas frutíferas. Brasília: Embrapa Informação Tecnológica, 2005. 221 p.

FERRIANI,A.P.; BORGES, M.V.;ZUFFELLATO-RIBAS, K.C.; CARPANEZZI, A.A.; KOEHLER, H.S. Influência da época do ano e das diferentes formas de aplicação de ácido naftaleno acético (ANA) no enraizamento de Mikania micrantha Kunth. Revista Brasileira de Plantas Medicinais, v.9, n.2, p.102-107, 2007.

GOSCH, C.; NAGESH, K.M.; THILL, J.; MIOSIC, S.; PLASCHIL, S.; MILOSEVIC, M.; OLBRICHT, K.; EJAZ, S.; ROMPEL, A.; STICH, K.; HALBWIRTH, H. Isolation of dihydroflavonol 4-reductase cDNA clones from Angelonia x angustifolia and heterologous expression as GST fusion protein in Escherichia coli. PLOS ONE, v.9, n.9, 2014. DOI: https://doi.org/10.1371/journal. pone. 0107755
GROLLI, P.R. Propagação de plantas ornamentais. In: PETRY, C. (Org.). Plantas ornamentais - aspectos para a produção. 2ed. Passo Fundo: Universidade de Passo Fundo, 2008. p.59-69.

KÄMPF, A.N. Produção comercial de plantas ornamentais. Guaíba: Agrolivros, 2005. 256p.

KERBAUY, G.B. Fisiologia Vegetal. 2ed. Rio de Janeiro: Guanabara Koogan, 2008. 454p.

LIMA, C.C.L.; OHASHI, S.T. Substratos no enraizamento de estacas provenientes de mudas de Schizolobium parahyba var. amazonicum. Enciclopédia Biosfera, v.13, n.24, p.1270-1282, 2016. DOI: 10.18677/Enciclopedia Biosfera 2016112

LONE, A.B.; UNEMOTO, L.K.; YAMAMOTO, L.Y.; COSTA, L.; SCHNITZER, J.A.; SATO, A.J.; RICCE, W. da S.; ASSIS, A.M. de; ROBERTO, S.R. Enraizamento de estacas de azaléia (Rhododendron simsii Planch.) no outono em AIB e diferentes substratos. Ciência Rural, v.40, n.8, p.1720-1725, 2010. DOI: http://dx.doi.org/10.1590/S010384782010000800008

MACHADO, I.C.; VOGEL, S.; LOPES, A.V. Pollination of Angelonia cornigera Hook. (Scrophulariaceae) by long legged, oil collecting bees in NE Brazil. Plant Biology, v.4, n.3, p.352-359, 2002. DOI: https://doi. org/10.1055/s-2002-32325

NEVES, T. dos S.; CARPANEZZI, A.A.; ZUFFELLATORIBAS, K.C.; MARENCO, R.A. Enraizamento de corticeira-da-serra em função do tipo de estaca e variações sazonais. Pesquisa Agropecuária Brasileira, v.41, n.12, p.1699-1705, 2006. DOI: http://dx.doi.org/10.1590/S0100204X2006001200003

PAIVA, R.; OLIVEIRA, L.M. de; NOQUEIRA, R.C.; SANTOS, B.R. dos; MARTINOTTO, C.; PAIVA, P.D. de O.; MENEGUCCI, J.L.P. Aspectos fisiológicos da produção de flores e plantas ornamentais. Informe Agropecuário, v. 26, n.227, p.73-84, 2005.

PLASCHIL, S.; OLBRICHT, K. Histogenetic variation in flowers of Angelonia Humb. et Bonpl. Journal of Applied Botany and Food Quality, v.82, n.1, p.41-46, 2008.

REFLORA. Jardim Botânico do Rio de Janeiro. Available at: <http://floradobrasil.jbrj.gov.br/>; Acessed on: February 03, 2018. 
REIS，D.J.; REIS，R.L.; CHALFUN， N.N.J.; LIMA, L.C.D.O. Efeito do estiolamento e do ácido indolbutírico no enraizamento de estacas do porta-enxerto Pyrus calleryana Dcne. Ciência e Agrotecnologia, v.24, n.4, p.931-938, 2000.

SANTORO, P.H.; MIKAMI, A.Y; SOUZA, S.G.H. de; ROBERTO, S.R. Influência de folhas e lesões na base de estacas herbáceas no enraizamento de goiabeira da seleção 8501-9. Semina: Ciências Agrárias, v.31, n.2, p.289-294, 2010. DOI: https://doi.org/10.5433/1679$0359.2010 \mathrm{v} 31 \mathrm{n} 2 \mathrm{p} 289$

SANTOS, F.M.; PINTO, J.E.B.P.; ALVARENGA, A.A.; OLIVEIRA, J.A.; OLIVEIRA, A.A.; OLIVEIRA, L.P. Produção de mudas de Aloysia gratissima (Gillies and Hook.) Tronc. por meio da propagação sexuada e assexuada. Revista Brasileira de Plantas Medicinais, v.11, n.2, p.130-136, 2009. DOI: http://dx.doi.org/10.1590/ S1516-05722009000200003

STUMPF, E.R.T., BARBIERI, R.L., HEIDEN, G. Cores e formas no Bioma Pampa: plantas ornamentais nativas. Pelotas: Embrapa Clima Temperado, 2009. 276 p.
TAIZ, L.; ZEIGER, E. Fisiologia vegetal. 5ed. Porto Alegre: Artmed, 2013.

TEDESCO, M.; GRZEÇA, G.T.; WINHELMANN, M.C.; PAOLAZZI, J.; SCHAFER, G. Propagação de Podranea ricasoliana (Tanfani) Sprague por estaquia. Enciclopedia Biosfera, v.13, n.24, p.855-862, 2016. DOI: 10.18677/ EnciBio_2016B_081

TROPICOS. Missouri Botanical Garden. St. Louis. Available at: < http://www.tropicos.org/NameSearch.as px? name=Angeloniaandcommonname $>$; Accessed on: February 032018.

YAMAMOTO, L.Y; KOYAMA, R.; BORGES, W.F.S.; ANTUNES, L.E.C.; ASSIS, A.M. de; ROBERTO, S.R. Substratos no enraizamento de estacas herbáceas de amorapreta Xavante. Ciência Rural, v.43, n.1, p.15-20, 2013. 